\title{
Design thinking i blended librarianship - nowe tendencje w bibliotekarstwie amerykańskim
}

\section{Wprowadzenie}

Z orientowanie na użytkownika w działalności współczesnych bibliotek jest kwestią oczywistą i niewymagającą szerszych komentarzy, biblioteki bowiem jako instytucje usługowe muszą opracowywać swoją ofertę, biorąc pod uwagę potrzeby i oczekiwania klientów. Warto przy tym ciągle poszukiwać nowych metod, dzięki którym można te oczekiwania najlepiej określić.

Zjawiskami mającymi wpływ na kształtowanie się potrzeb użytkowników bibliotek są: przyrost wiedzy ludzkiej, ewolucja metod i form uczenia się, rozwój systemów oświaty i ich demokratyzacja, poszerzanie i różnicowanie działalności praktycznej człowieka oraz nasilanie się kontaktów międzyludzkich ${ }^{1}$. W ostatnich dwudziestu latach istotnym czynnikiem przemian stał się gwałtowny rozwój technologii informacyjnych i komunikacyjnych. Spowodował on znaczące przeobrażenia w sposobie korzystania $\mathrm{z}$ informacji i usług $\mathrm{w}$ bibliotekach, które oferują dziś m.in. dostęp on-line (do katalogów, baz danych, czasopism elektronicznych, e-podręczników), elektroniczne zamawianie książek czy dokonywanie prolongat.

Biblioteki zareagowały też na powszechnie stosowane $\mathrm{w}$ środowisku cyfrowym narzędzia Web 2.0 i zaimplementowały je do organizowa-

${ }^{1} \mathrm{~J}$. Ratajewski, Wprowadzenie do bibliotekoznawstwa, czyli wiedza o bibliotece $w$ różnych dawkach, Warszawa 2002, s. 30. 
nia własnej działalności. Dopuściły użytkowników do współtworzenia i współdecydowania o kształcie biblioteki, przede wszystkim w sieci, na skutek czego powstały biblioteczne blogi, fora dyskusyjne oraz serwisy zakładkowe. Pojawiła się także możliwość kontaktowania się z bibliotekarzem poprzez komunikatory internetowe.

Mimo zarysowanych zmian nadal poszukiwane są metody unowocześniania i usprawniania działalności bibliotek, pozwalające na usankcjonowanie konieczności ich funkcjonowania w społeczeństwie informacyjnym. Stąd w niniejszym artykule autorka podjęła próbę przybliżenia dwóch koncepcji, które w bibliotekarstwie amerykańskim pojawiły się w ostatniej dekadzie i które wydają się istotną propozycją wspomagającą przeobrażenia w bibliotekach. Pierwsza z nich to wykorzystanie do opracowywania programów, usług i strategii bibliotecznych metody design thinking, druga będąca reakcją i być może pewnego rodzaju antidotum na pesymistyczne przewidywania o rychłym końcu bibliotek - idea blended librarianship.

\section{Design thinking i jego zastosowanie w bibliotekarstwie}

D iblioteki, aby przetrwać, muszą ulepszać swoje usługi, które - jak pisze

Bichael Gorman - definiują przecież bibliotekarstwo. Każdy aspekt bibliotekarstwa, każde działanie podejmowane przez bibliotekarzy powinno być rozpatrywane przez pryzmat usług ${ }^{2}$. Usługi, tak jak inne produkty biblioteczne, należy jednak ciągle udoskonalać, by jak najefektywniej zaspokajać potrzeby użytkowników. W tym celu można wykorzystywać metody projektowe. Jedną z nich jest design thinking, czyli myślenie projektowe. Metoda ta była stosowana początkowo w studiach projektowych, skąd została przeszczepiona do koncernów, które zaczęły prowadzić swoje projekty właśnie z wykorzystaniem design thinking ${ }^{3}$. Po pewnym czasie okazało się, że może być ona użyteczna nie tylko w wielkich korporacjach, ale także w firmach i organizacjach - również publicznych - dążących do opracowania nowatorskiego produktu, usługi oraz usprawnienia metod działania ${ }^{4}$. Co ważne, metoda design thinking nie wymaga wielkich nakła-

2 M. Gorman, Our enduring values. Librarianship in the 21st century, Chicago-London 2000, s. 75.

3 B. Serafiński, Design thinking - myśl rozwiq̨zaniami, „Magazyn THINKTANK” 2009, nr 2, s. 40.

4 Tamże. 
dów finansowych, lecz dyscypliny w jej stosowaniu. Firmą promującą design thinking jest IDEO ${ }^{5}$.

Według Tima Browna - dyrektora generalnego IDEO - design thinking to metodologia przenikająca całe spektrum innowacyjnej, zorientowanej na człowieka działalności. Ta innowacyjność jest zasilana przez zrozumienie, czego ludzie oczekują i potrzebują, co lubią, a czego nie. Dopiero w kolejnej fazie procesu design thinking są wytwarzane produkty i usługi ${ }^{6}$. Myślenie projektowe wykorzystuje wrażliwość i metody pracy projektanta do zaspokojenia potrzeb klientów za pomocą tego, co jest technologicznie wykonalne i co realna strategia biznesowa może przekształcić w wartość dla klienta i szansę rynkową7.

Na proces design thinking składa się pięć kroków:

- Zrozumienie: należy poznać potrzeby i oczekiwania użytkowników oraz to, jak postrzegają oferowane im produkty i usługi;

- Obserwowanie: konieczne jest przyglądanie się ludziom w rzeczywistych sytuacjach, aby zaobserwować, jak oni pracują, co wprawia ich w zakłopotanie, co lubią, a czego nie lubią i jak ich potrzeby będą najlepiej zaspokojone;

- Wizualizacja: należy tworzyć nowe rozwiązania, ulepszać te istniejące, biorąc pod uwagę, czy będą one przydatne z punktu widzenia klientów; na tym etapie ważne jest zaangażowanie pracowników danej instytucji i zgłaszanie swoich propozycji oraz stosowanie technik takich, jak burze mózgów;

- Ocena i udoskonalenie: bardzo istotne w myśleniu projektowym jest tworzenie prototypów, symulacji czy realizacje filmów, w celu prezentowania i testowania innowacji, a następnie ich ulepszania;

- Implementacja: najdłuższy i najtrudniejszy etap procesu projektowania, polegający na wytworzeniu nowego produktu lub usługi i zaoferowaniu ich użytkownikom ${ }^{8}$.

Istotną cechą design thinking jest koncentracja na człowieku, rzeczywistym lub potencjalnym odbiorcy produktu czy usługi, której efektem będzie opracowanie innowacji lepiej odzwierciedlającej jego potrzeby ${ }^{9}$.

${ }^{5}$ IDEO to powstała w 1991 r. firma konsultingowa, która pracowała m.in. dla takich firm, jak: Bank of America, Nike, Motorolla, Microsoft, Lucent Technologies, Kraft, Hewlett Packard, Prada, Philips czy Toyota.

6 T. Brown, Design thinking, „Harvard Business Review”, June 2008, s. 86.

7 Tamże.

8 S. J. Bell, Design thinking, „American Libraries” 2008, vol. 39, iss. 1/2, s. 45.

9 Zob. T. Brown, dz. cyt., s. 90. 
Dlatego należy obserwować klientów korzystających z danej usługi czy produktu, ponieważ czasami użytkownicy nie są w stanie powiedzieć, dlaczego wybierają określony produkt zamiast innego. Poza tym dobrze byłoby, gdyby członkowie zespołu projektowego odwoływali się do swoich spostrzeżeń, a nie ustaleń poczynionych w badaniach konsumenckich, chociażby w badaniach fokusowych ${ }^{10}$. Ważnym elementem myślenia projektowego jest stworzenie zespołu projektującego, złożonego z osób o różnych kompetencjach, pracujących nie tylko w firmie, która chce wprowadzić innowacje, ale także poza nią. Istotną cechą design thinking jest też tworzenie prototypów swoich pomysłów, np. z kartonu, styropianu, symulacji komputerowych, wydruków na drukarkach 3D. Prototyp może być makietą produktu albo mieć formę filmu czy komiksu, który przedstawia korzystanie $\mathrm{z}$ usługi $\mathrm{w}$ formie narracji ${ }^{11}$.

Osoby, które myślą projektowo, winno charakteryzować kilka cech. Pierwszą jest empatia. Posługujący się nią pracownicy powinni potrafić wyobrazić sobie rzeczywistość $\mathrm{z}$ wielu punktów widzenia, $\mathrm{w}$ tym również klientów realnych i potencjalnych. Podejście „najpierw człowiek” oraz wyciąganie wniosków z zaobserwowanych szczegółów zapewniają znalezienie rozwiązań najbardziej właściwych i pożądanych. Równie ważne jest myślenie integracyjne, ponieważ osoby myślące projektowo nie ograniczają się jedynie do analizowania, lecz potrafią także dostrzec niezwykle istotne - i czasami sprzeczne - aspekty problemu, które doprowadzą do nowatorskich rozwiązań. Oczywiście, nieodzownym wyróżnikiem osób myślących projektowo jest optymizm, ponieważ przyjmują one, że nieważne, jak duży jest problem do rozwiązania, przynajmniej jedno rozwiązanie jest lepsze niż istniejący stan. Istotna jest także chęć eksperymentowania, gdyż znaczące innowacje nie są efektem stopniowych ulepszeń, a ci, którzy myślą projektowo, zadają pytania, analizują przeszkody i opracowują całkiem nowe kierunki rozwoju. Naturalnie, konieczna jest umiejętność współpracy. Chodzi nie tylko o to, że najlepsze wyniki osiąga się w efekcie pracy zespołowej, lecz także o to, że osoby w takiej grupie pracujące mają różne kwalifikacje i wykształcenie ${ }^{12}$.

Analiza przedstawionych zasad design thinking pozwala na sformułowanie wniosku o celowości wykorzystania tej metody w bibliotekarstwie. Stosowanie myślenia projektowego może usprawnić podejmowa-

10 B. Serafiński, dz. cyt., s. 41.

11 Tamże, s. 43.

12 T. Brown, dz. cyt., s. 87. 
nie działań innowacyjnych w bibliotekach. Do wspomnianego procesu tworzenia nowych i lepszych rozwiązań warto zaangażować pracowników tych placówek. Należy przekonać ich, że wprawdzie towarem w bibliotece jest informacja, lecz nie można traktować biblioteki tylko jako miejsca jej udostępniania. Bo gdy w bibliotece zabraknie wartości dodanej czy - jak ją nazywa Jacek Wojciechowski - wartości naddanej, nie będzie ona różniła się od innych instytucji świadczących usługi informacyjne niczym poza tym, że w bibliotekach są one bezpłatne. Należy więc wywołać u użytkowników pozytywne skojarzenia z biblioteką, np. poprzez stworzenie przyjaznej atmosfery, usunięcie barier uniemożliwiających korzystanie z niej, propozycję uczestnictwa w inicjatywach edukacyjnych i kulturalnych. Te z kolei można wypracować w trakcie procesu design thinking ${ }^{13}$, opierającego się głównie na dogłębnym poznaniu zachowań i potrzeb użytkowników. Przykładowo, obserwacje klientów i rozmowy z nimi wskazują, że dostęp do wypożyczalni, gdzie dokonuje się zwrotów książek, jest utrudniony, jeśli znajduje się ona na piętrze budynku i aby się do niej dostać, należy pozostawić okrycia wierzchnie i torby w szatni. Ponieważ niejednokrotnie czytelnicy chcą jedynie szybko oddać wypożyczone wcześniej dokumenty, biblioteka powinna uruchomić system tzw. szybkiego zwrotu książek w holu przy wejściu głównym. Początkowo może to być jedynie prowizoryczny regał przy stanowisku informacyjnym, a jeśli ten sposób przyjmie się, warto przemyśleć np. uruchomienie całodobowego systemu zwrotu książek na wzór bankowych wrzutni nocnych.

Z uwagi na to, że stosowanie design thinking w usprawnianiu działalności bibliotek jest koncepcją nową i ciągle rozwijającą się, stworzono Blended Librarians Online Learning Community ${ }^{14}$ - grupę bibliotekarzy, której działania koncentrują się m.in. wokół możliwości wykorzystania omawianej metody. Dzięki tej inicjatywie bibliotekarze mają okazję zapoznać się z ideą myślenia projektowego, jego metodyką i przykładami zastosowania. Sporo informacji na temat myślenia projektowego i jego wykorzystania w środowisku bibliotecznym można pozyskać także z blogu Designing Better Libraries ${ }^{15}$.

${ }^{13}$ S. J. Bell, dz. cyt., s. 48.

14 The Blended Librarian Portal [on-line] [dostęp 10 sierpnia 2010]. Dostępny w World Wide Web: http://blendedlibrarian.org.

${ }^{15}$ Designing better libraries, aktualizacja 25 marca 2010 [on-line] [dostęp 10 sierpnia 2010]. Dostępny w World Wide Web: http://dbl.lishost.org/blog/. 
W Stanach Zjednoczonych, gdzie zrodziła się koncepcja stosowania design thinking w bibliotekarstwie, można już odnotować przykład wykorzystania jej w praktyce. Podczas remontu i przebudowy Carnegie Library w Pittsburghu firma Maya Design, której zlecono przygotowanie projektu modernizacji biblioteki, rozpoczęła prace od przyjrzenia się jej użytkownikom. Obserwowano drogi przemieszczania się klientów, ich zachowania, sposób korzystania z zasobów biblioteki. W ten sposób odkryto, że środowisko biblioteki jest „przeładowane” informacjami, co wprawia użytkowników w zakłopotanie i onieśmielenie ${ }^{16}$. Ponadto, niektóre z informacji okazały się na tyle słabo wyeksponowane, że czytelnik nie był pewny, czy biblioteka jest zamknięta, czy otwarta, czy w danym miejscu można uzyskać informację od bibliotekarza, a jeśli tak, to jakiego rodzaju. Dopiero po analizie zebranych danych i wyciągnięciu z nich wniosków w bibliotece przeprowadzono działania modernizacyjne, zarówno w zakresie aranżacji wnętrza, stosowanych piktogramów i tablic informacyjnych na zewnątrz i wewnątrz budynku, jak i jej witryny internetowej ${ }^{17}$.

Również w bibliotece University of Rochester w Nowym Jorku są prowadzone badania, które mają ujawnić zachowania jej użytkowników. Celem tych działań jest nie tyle poznanie sposobów na podniesienie satysfakcji klienta, ile pomoc użytkownikom w realizacji ich prac poprzez usunięcie napotykanych barier i niedogodności ${ }^{18}$.

Poprzez obserwację zachowań klientów utrwalonych na fotografiach i filmach, wciąganie $w$ dyskusję na temat biblioteki oraz tego, $w$ jaki sposób z niej korzystają, bibliotekarze mogą zrobić pierwszy krok w kierunku procesu design thinking, mianowicie zidentyfikują problem. W design thinking chodzi bowiem nie o szybkie opracowanie rozwiązań, lecz dogłębne poznanie problemu. Jeśli zostanie on dobrze rozpoznany, rozwiązania nasuną się same ${ }^{19}$.

6 S. J. Bell, dz. cyt., s. 45-46.

17 Zob. szerzej S. Jackson, Information architecture and customer service: presentation to Association for Library Service to Children September 2006 [on-line]. Presentations. Carnegie Library of Pittsburgh [dostęp 10 sierpnia 2010]. Dostępny w World Wide Web: http://www.carnegielibrary.org/presentations/jackson/.

${ }_{18}^{18}$ S. J. Bell, dz. cyt., s. 46.

19 Tamże. 


\section{Blended librarianship - sposób na przetrwanie bibliotek akademickich?}

Z deą stosowania design thinking w bibliotekarstwie wiąże się koncepcja blended librarian, którą stworzyli w 2004 r. Steven J. Bell oraz John D. Shank. Według nich blended librarian to bibliotekarz akademicki, który łączy standardowe umiejętności bibliotekarskie z kompetencjami w zakresie technologii informatycznych oraz projektowania i wdrażania metod i technik przydatnych $\mathrm{w}$ procesie dydaktycznym ${ }^{20}$. Gdzie należy szukać genezy tej koncepcji? Wspomniani autorzy, skądinąd bibliotekarze akademiccy, zauważyli, że rozwój nowych technologii spowodował ogromne zmiany w szkolnictwie wyższym. Bibliotekarstwo akademickie szybko je zaimplementowało. Bibliotekarze akademiccy pozyskali umiejętności czysto techniczne, które połączyli z umiejętnościami bibliotekarskimi i wiedzą ogólną ${ }^{21}$. Zaniedbaną jednak sferą pozostały kwestie związane z projektowaniem, tworzeniem, implementacją i ewaluacją kursów oraz szkoleń, a także opracowywaniem materiałów dydaktycznych, które wspierałyby jednostki dydaktyczne w procesie kształcenia. Zagadnienia te, jak twierdzili Bell i Shank, były pomijane w procesie kształcenia bibliotekarzy, podczas gdy, jak wiadomo, biblioteka akademicka jest ważnym elementem procesów dydaktycznych w środowisku uczelnianym $^{22}$. Na problematykę braku łączności pomiędzy zintegrowanymi systemami uczelnianymi a systemami bibliotecznymi oraz ograniczonego zakresu stosowanych w bibliotekach akademickich form dydaktycznych zwraca się także uwagę w polskiej literaturze bibliotekoznawczej ${ }^{23}$. Wykładowcy pomijają informacje o szkoleniach bibliotecznych, nie informu-

${ }^{20} \mathrm{~J}$. D. Shank, The blended librarian: a job announcement analysis of the newly emerging position of instructional design librarian, „College \& Research Libraries” 2006, vol. 67, iss. 6, s. 515.

${ }^{21}$ S. J. Bell, J. D. Shank, The blended librarian: a blueprint for redefining the teaching and learning role of academic librarians. College and Research Libraries News [on-line] 2004, vol. 65, no. 7 [dostęp 10 sierpnia 2010]. Dostępny w World Wide Web: http://www. acrl.org/ala/mgrps/divs/acrl/publications/crlnews/2004/jul/blendedlibrarian.cfm.

22 Tamże.

${ }^{23}$ Zob. np. E. J. Kurkowska, Wykorzystanie Internetu $w$ działalności dydaktycznej polskich bibliotek uniwersyteckich, [w:] Biblioteka $w$ procesie dydaktycznym i badaniach naukowych. III Konferencja Biblioteki Politechniki Łódzkiej, Łódź, 25-27 czerwca 2008 r.: materiały konferencyjne, Łódź 2008, s. 397; J. Stępniak, Szkoła wyższa i jej biblioteka - warunki integracji, [w:] tamże, s. 9-24. 
ją, że zalecana literatura znajduje się w bibliotece, udostępniają materiały dydaktyczne niebędące częścią oferty systemu bibliotecznego. Prowadzi to do stopniowego wykluczania biblioteki z grupy jednostek niezbędnych w procesie kształcenia ${ }^{24}$.

Wspomniane konstatacje doprowadziły do powstania koncepcji blended librarian. W ten sposób starano się zachęcić bibliotekarzy do poszerzenia ich umiejętności bibliotekarskich i informacyjnych o te związane z projektowaniem, realizacją i oceną szkoleń, do których należałoby wykorzystać wiedzę teoretyczną dotyczącą procesu uczenia się i nauczania oraz możliwości aplikacji nowoczesnych metod i technik, jak system zdalnego nauczania, przygotowywanie multimedialnych materiałów dydaktycznych, telekonferencje, system wiki itp. Bibliotekarz akademicki miał stać się profesjonalistą, którego umiejętności pozwoliłyby na aplikację nowych technologii na uczelni, co przyczyniłoby się do udoskonalenia procesów uczenia się i nauczania. Podkreślano jednak, że alfabetyzacja informacyjna (ang. information literacy) jest tylko jednym aspektem włączania się biblioteki akademickiej w realizowany proces dydaktyczny ${ }^{25}$. Blended librarian ma bowiem także wspomagać studentów i nauczycieli akademickich w realizacji ich zadań dydaktycznych i naukowych.

$\mathrm{Z}$ terminem blended librarian wiąże się pojęcie blended librarianship, co można przetłumaczyć jako bibliotekarstwo komplementarne. Oto zasady, które mu przyświecają:

1. Przyjęcie przez bibliotekę akademicką pozycji lidera w zakresie wprowadzania innowacji na uczelni ma na celu realizowanie misji dostarczania usług bibliotecznych i informacyjnych.

2. Konieczne jest rozpowszechnienie na uczelni/wydziale informacji o podejmowanych inicjatywach z zakresu information literacy, co ułatwi zaangażowanie się biblioteki w proces dydaktyczny.

3. Projektowanie programów szkoleniowych i edukacyjnych oraz zajęć w celu pomocy użytkownikom w korzystaniu z biblioteki oraz podniesienia ich kompetencji z zakresu information literacy zapewni im uzyskanie niezbędnej wiedzy i umiejętności, a w dalszej perspektywie osiągnięcie sukcesu.

${ }^{24}$ J. Stępniak, dz. cyt., s. 14.

${ }^{25}$ S. J. Bell, J. D. Shank, Intentional design: how blended librarians use design thinking to enhance library services [on-line]. The Blended Librarian Portal [dostęp 10 sierpnia 2010]. Dostępny w World Wide Web: http://blendedlibrarian.org/presentations/cla08presentation.pdf. 
4. Współpraca z projektantami i innymi profesjonalistami w zakresie szkoleń jest niezbędna do rozwijania programów, usług i zasobów, co ułatwi z kolei realizację misji biblioteki akademickiej.

5. Wprowadzanie zmian $\mathrm{w}$ bibliotece można zwiększyć poprzez współpracę z projektantami i technologami.

6. Zmiana relacji biblioteki z władzami uczelni/wydziału wymaga podjęcia wysiłku w celu przeprowadzenia kursów szkoleniowych, do których wykorzysta się i zasoby placówki, i nowe technologie. Konieczne jest podejmowanie przez biblioteki współpracy z innymi profesjonalistami w celu podniesienia jakości uczenia się studentów oraz dokonywania oceny w zakresie dostępu i pozyskiwania informacji ${ }^{26}$.

W koncepcji blended librarianship ważne jest zwrócenie uwagi bibliotekarzy na konieczność podjęcia działań, które mają zapobiegać marginalizacji biblioteki w strukturze uczelni. Biblioteka bowiem straciła swoją rolę centrum informacji, do czego przyczyniło się powstanie systemów zdalnego nauczania, platform cyfrowych, e-książek i e-czasopism, podręczników dostępnych on-line czy wyszukiwarek internetowych ${ }^{27}$. Tymczasem, skoro zadaniem bibliotekarzy akademickich jest pomoc studentom i nauczycielom akademickim $\mathrm{w}$ procesach dydaktycznych oraz prowadzeniu prac badawczych, to muszą oni wyjść z propozycją współpracy, nie zaś jedynie czekać na użytkownika w bibliotece ${ }^{28}$. Powinni być innowacyjni, opracowywać i implementować nowe usługi, wykorzystując wiedzę i nowe technologie, takie jak: blogi, podcasty, multimedia, systemy wiki, metody i techniki e-learningowe. Bibliotekarze akademiccy winni wspierać proces uczenia się studentów zarówno w przestrzeni realnej, jak i wirtualnej. Dlatego należy połączyć usługi biblioteczne i informacyjne z procesem dydaktycznym poprzez wykorzystanie metody design thinking $^{29}$. Jak już wcześniej wspomniano, do jej cech charakterystycznych zaliczają się: umiejętność empatycznego podejścia do potrzeb użytkownika, zaproponowanie nowych rozwiązań poprzez przetestowanie prototypów

26 S. J. Bell, J. D. Shank, The blended librarian: a blueprint...

27 B. Sinclair, The blended librarian in the learning commons: new skills for the blended library. College and Research Libraries News [on-line] 2009, vol. 70, no. 9 [dostęp 10 sierpnia 2010]. Dostępny w World Wide Web: http://www.ala.org/ala/mgrps/divs/acrl/ publications/crlnews/2009/oct/blended_librarian.cfm.

${ }_{28}$ Por. S. J. Bell, J. D. Shank, Academic librarianship by design: a blended librarian's guide to the tools and techniques, Chicago 2007, s. 1; B. Sinclair, dz. cyt.

${ }^{29}$ B. Sinclair, dz. cyt. 
oraz ocena, czy i w jakim stopniu wdrażana innowacja odpowiada na zapotrzebowanie użytkowników.

Przykładowo, opracowując program zdalnego szkolenia bibliotecznego, należy najpierw zdobyć informację o przyszłych użytkownikach oraz ich potrzebach, następnie opracować prototyp, np. w postaci prezentacji multimedialnej, który zostanie przedstawiony grupie zainteresowanych. Po naniesieniu zmian i poprawek opracowany zdalny program szkoleniowy musi zostać oceniony pod kątem zaspokojenia potrzeb użytkowników w tym zakresie ${ }^{30}$. Osoba stosująca metodę design thinking na pierwszy plan wysuwa bowiem potrzeby użytkowników.

Design thinking może być więc sposobem, w jaki bibliotekarze akademiccy będą analizowali swoje usługi i zasoby, aby udoskonalić metody ich dostarczania i wykorzystania, a przy tym będą mogli usunąć bariery, jakie napotykają studenci i pracownicy uczelni w dostępie do nich ${ }^{31}$. Celem nadrzędnym jest zatem, uwzględniając przede wszystkim potrzeby użytkowników, polepszanie swojej oferty, tak aby jak najbardziej przylegała ona do oczekiwań beneficjentów. Skupienie się na sposobach korzystania z danej usługi czy zasobów biblioteki przez użytkowników, obserwacja ich zachowań w środowisku biblioteki zagwarantują sukces projektowanych zmian. Aby jednak wprowadzać zmiany w bibliotece z wykorzystaniem design thinking, konieczne jest uformowanie zespołu, który będzie składał się z osób o zróżnicowanych kompetencjach. Nie wszyscy bowiem bibliotekarze muszą być kompetentni w zakresie możliwości aplikacji nowych technologii, nie wszyscy mają wystarczające zdolności, by opracować prototyp produktu, nie dla wszystkich prowadzenie obserwacji i rozmów z użytkownikami lokujących się w obszarze badań etnograficznych jest rzeczą prostą. Skład zespołu powinien zostać ukonstytuowany w toku przemyślanej selekcji.

W koncepcji bibliotekarstwa komplementarnego istotną rolę odgrywa zatem stosowanie metody design thinking, której zasadniczą cechą jest umiejscowienie człowieka i innowacji w centrum zainteresowań bibliotekarzy akademickich ${ }^{32}$. Skoro biblioteka akademicka ma spełniać ważną funkcję w procesie dydaktycznym uczelni, konieczne staje się większe jej zaangażowanie w realizację tego procesu. Zamiast czekać, aż studenci przyjdą do biblioteki po informacje - a niektórzy przychodzą do niej

${ }^{30}$ Por. S. J. Bell, J. D. Shank, Academic librarianship by design..., s. 21.

31 Tamże, s. 23.

32 Tamże, s. 24. 
dopiero na etapie pisania prac dyplomowych - warto zastanowić się nad tym, jakie są ich potrzeby informacyjne. Z kolei stosując metodę design thinking, można wypracować sposób ich zaspokajania. Jak sugerują Bell i Shank, to angażowanie się bibliotek akademickich w proces dydaktyczny jest jedynym sposobem na ich przetrwanie ${ }^{33}$. Blended librarian szuka nowych możliwości poprawy usług bibliotecznych oferowanych studentom i pracownikom uczelni ${ }^{34}$. Jedną z metod jest podejmowanie działalności szkoleniowej prowadzonej w trybie zdalnym. Nie chodzi tu jedynie o przewodniki on-line po bibliotece, szkolenia biblioteczne organizowane dla studentów pierwszego roku czy bardziej zaawansowane szkolenia dla doktorantów bądź pracowników naukowo-dydaktycznych, zapoznające ich z nowymi zasobami i strategiami wyszukiwawczymi. Blended librarian winien wspierać proces dydaktyczny poprzez współdziałanie z wykładowcami w celu opracowywania bloków programowych realizowanych w systemie nauczania zdalnego, przygotowywania zestawień bibliograficznych, prezentacji multimedialnych oraz pakietów dydaktycznych na potrzeby konkretnych zajęć.

\section{Podsumowanie}

imo że problematyka stosowania design thinking w bibliotekarstwie oraz koncepcja blended librarianship w ścisłym rozumieniu tych terminów nie były przedmiotem refleksji teoretycznej w rodzimej literaturze bibliologicznej, a tym bardziej nie zaimplementowano ich na grunt polskiego bibliotekarstwa, pewne treści z nimi powiązane pojawiały się już wcześniej. Wielokrotnie zwracano uwagę na konieczność udoskonalania działalności bibliotek, oferowanych usług i programów, aby jak najlepiej zaspokajać potrzeby użytkowników. Podkreślano, że biblioteki, zwłaszcza uczelniane, mają nie tylko obsługiwać, ale także uczyć, jak najlepiej wykorzystać potencjał bibliotecznych zasobów własnych i obcych oraz krytycznie oceniać informację. Nie oznacza to bynajmniej, że design thinking i blended librarianship nie wnoszą nic nowego do polskiego bibliotekarstwa. W pierwszym przypadku jest to wykorzystanie metody projektowej stosowanej do niedawna jedynie w sektorze biznesowym. W drugim jest to propozycja zaangażowania się bibliotekarzy akademic-

\footnotetext{
33 Tamże, s. 7.

34 Tamże, s. 2.
} 
kich nie tylko w szkolenie użytkowników bibliotek, ale także wykorzystanie ich wiedzy i umiejętności do przeprowadzania procesu dydaktycznego na uczelni, przede wszystkim w trybie kształcenia na odległość. Te nowe idee powoli są aplikowane w bibliotekach amerykańskich. Czy mają szansę przyjąć się na polskim gruncie? Powinny.

\section{Design thinking and blended librarianship - new trends in the American librarianship Abstract}

The article introduces two new concepts that have emerged in American librarianship in recent years. The first one, called design thinking, is applied to improve library performance. Although originating in business sector, it is now being successfully used in American libraries. The second one, blended librarianship, has emerged in response to library marginalization in academic environment. According to this concept, the blended librarian is a type of academic librarian who successfully combines traditional library skills with IT skills, including design and application of modern learning and teaching tools. This broad scope of tasks appointed to librarians will hopefully improve the libraries' image. As a result, the academic libraries will be considered not only a place to borrow books, but also an important place to support teaching and learning activity. 